\title{
Udostępnienie przez organ administracji rządowej - w trybie ustawy o dostępie do informacji publicznej - korespondencji w sprawie interwencji poselskiej organowi gminy, którego dotyczy ta interwencja ${ }^{1}$
}

\begin{abstract}
Submitting by a government administration body - under the Act on Access to Public Information - correspondence regarding a Deputy's intervention to a communal body being an addressee of the intervention (WAP-337/18): The purpose of the Act on Access to Public Information is to inform citizens about public matters, and not to obtain information from entities belonging to administration by other administrative authorities. A government administration body is not obliged to provide information to a local selfgovernment administration body, because, as an example, communal authorities cannot be qualified as entities specified in the Act.
\end{abstract}

Keywords: publicadministration, publicinformation,Deputy'sintervention,Deputy, local government

Słowa kluczowe: administracja publiczna, informacja publiczna, interwencje, poseł, samorząd terytorialny

\section{Przedmiot opinii}

Przedmiotem opinii jest odpowiedź na następujące pytanie: „czy organ administracji publicznej (urząd wojewódzki, ministerstwo) w trybie ustawy o dostępie do informacji publicznej jest zobowiązany do udostępnienia treści korespondencji poselskiej wraz z załącznikami, stanowiącymi podstawę do tej interwencji poselskiej, organowi gminy, którego dotyczy ta interwencja?”.

1 Opinia prawna na temat udostępnienia przez organ administracji rządowej $w$ trybie ustawy o dostępie do informacji publicznej korespondencji w sprawie interwencji poselskiej organowi gminy, którego dotyczy ta interwencja sporządzona 2 marca 2018 r. na zlecenie posła Klubu Parlamentarnego Prawo i Sprawiedliwość; BAS-WAP 337/18. 
Opinia uwzględnia stan prawny na dzień jej sporządzenia. W opinii wykorzystano postanowienia następujących aktów prawnych:

- Konstytucja Rzeczypospolitej Polskiej z 2 kwietnia 1997 r., Dz.U. nr 78, poz. 483, ze zm.,

- ustawa z 6 września 2001 r. o dostępie do informacji publicznej, t.j. Dz.U. 2016, poz. 1764, ze zm.; dalej: u.d.i.p.

- ustawa z 6 maja 1996 r. o wykonywaniu mandatu posła i senatora, t.j. Dz.U. 2016, poz. 1510, ze zm.

\section{Uzasadnienie prawne}

1. Kwestia, do której odnosi się sformułowane na wstępie pytanie, wymaga rozstrzygnięcia, czy organy administracji publicznej (w tym organy administracji rządowej, takie jak urząd wojewódzki czy ministerstwo, oraz organy samorządu terytorialnego, czyli np. organy gminy) mogą składać wnioski o udostępnienie informacji publicznych. Bez znaczenia dla tej kwestii pozostaje fakt, że informacje, o których mowa w pytaniu, dotyczą materiałów (w tym korespondencji poselskiej) związanych z interwencją poselską podjętą na podstawie art. 20 ust. 1 ustawy z 6 maja 1996 r. o wykonywaniu mandatu posła i senatora.

Zgodnie $\mathrm{z}$ art. 61 ust. 1 Konstytucji RP obywatel ma prawo uzyskiwania informacji o działalności organów władzy publicznej oraz osób pełniących funkcje publiczne. Prawo to obejmuje również uzyskiwanie informacji o działalności organów samorządu gospodarczego i zawodowego, a także innych osób oraz jednostek organizacyjnych w zakresie, w jakim wykonują one zadania władzy publicznej i gospodarują mieniem komunalnym lub majątkiem Skarbu Państwa. Regulacją będącą rozwinięciem powyższego prawa jest ustawa z 6 września 2001 r. o dostępie do informacji publicznej. Powołany przepis art. 61 ust. 1 Konstytucji RP kształtuje prawo do informacji publicznej jako prawo obywatelskie, natomiast ustawa o dostępie do informacji publicznej (w art. 2 ust. 1) dostęp do informacji publicznej przyznaje „każdemu”.

Kwestia ustalenia kręgu podmiotów uprawnionych do uzyskiwania informacji publicznej na podstawie ustawy o dostępie do informacji publicznej była wielokrotnie przedmiotem rozważań sądów administracyjnych oraz doktryny.

W orzecznictwie wskazuje się, że użyty w art. 2 ust. 1 u.d.i.p. zwrot „każdy” należy rozumieć jako każdy człowiek (osoba fizyczna) lub podmiot prawa prywatnego. Naczelny Sąd Administracyjny w Warszawie w wyroku z 30 stycznia 2014 r., wydanym w sprawie o sygn. I OSK 1982/13, ${ }^{2}$ stwierdził, że: [u]żywając $w$ art. 2 ust. 1 ustawy o dostępie do informacji publicznej pojęcia „każdemu”, ustawodawca precyzuje zastrzeżone $w$ Konstytucji obywatelskie uprawnienie, wskazu-

2 LEX nr 1463438. 
jąc, że każdy może z niego skorzystać na określonych w tej ustawie zasadach. Zwrot „każdy” należy rozumieć jako każdy człowiek lub podmiot prawa prywatnego. Termin „każdy” nie może być inaczej rozumiany, zważywszy na cel i sens ustawy o dostępie do informacji publicznej, przyjętej dla urzeczywistnienia idei transparentności władzy publicznej. Takie rozumienie pojęcia „każdemu” potwierdza stanowisko Trybunału Konstytucyjnego, zaprezentowane w wyroku $z$ dnia 25 maja 2009 r., o sygn. akt SK $54 / 08$.

Jednocześnie sądy uznają, że celem ustawy o dostępie do informacji publicznej jest informowanie obywateli o stanie „spraw publicznych”, a nie, jak to stwierdzono w postanowieniu Wojewódzkiego Sądu Administracyjnego w Warszawie z 18 lutego 2010 r., sygn. akt II SAB/Wa 197/09, ${ }^{3}$ zdobywanie przez organy administracji publicznej informacji od innych podmiotów.

Sądy administracyjne podkreślają również, że przy dokonywaniu wykładni użytego w art. 2 ust. 1 u.d.i.p. pojęcia „każdy” należy wziąć pod uwagę przede wszystkim intencje projektodawców, a z uzasadnienia do poselskiego projektu ustawy o dostępie do informacji publicznej wynika, że celem tym było zapewnienie swego rodzaju „społecznej kontroli” nad organami władzy publicznej, transparentności działania tych organów i zapewnienie aktualnej wiedzy o stanie państwa, samorządów i instytucji publicznych oraz ich majątku4.

Wojewódzki Sąd Administracyjny w Warszawie w wyroku z 13 grudnia 2012 r., sygn. akt II SAB/Wa 386/12, ${ }^{5}$ uznał, że ustawa o dostępie do informacji publicznej służy realizacji konstytucyjnego prawa dostępu do wiedzy na temat funkcjonowania organów władzy publicznej. Racjonalny ustawodawca, używając $w$ art. 2 ust. 1 ustawy pojęcia „każdemu”, precyzuje zastrzeżone $w$ Konstytucji obywatelskie uprawnienie, wskazując, że każdy może z niego skorzystać na określo-

3 WSA wyraził następujące stanowisko: (...) termin ten [każdy] nie może odnosić się do organów administracji publicznej, gdyż ustawa ta ma służyć do „bezpłatnego informowania obywateli w sposób i czasie zapewniający aktualna wiedzę o stanie państwa, samorządów i instytucji publicznych oraz ich majątku" (Uzasadnienie do poselskiego projektu ustawy o dostępie do informacji publicznej - druk sejmowy nr 2094 z 30.VI.2000 r., s. 18). Celem ustawy z 6.IX.2001 r. o dostępie do informacji publicznej jest informowanie obywateli o stanie „spraw publicznych", a nie zdobywanie przez organy administracji publicznej informacji od innych podmiotów (por. wypowiedź T. Górzyńskiej zamieszczona w Biuletynie nr 3614/III kad. Komisja Nadzwyczajna do rozpatrzenia projektów ustaw dotyczacych prawa obywateli do uzyskiwania informacji o działalności organów władzy publicznej oraz osób petniących funkcje publiczne, a także dotyczących jawności procedur decyzyjnych /nr 3/). Tak więc, biorąc pod uwage cel i sens ustawy o dostępie do informacji publicznej, przyjętej przecież dla urzeczywistnienia idei transparentności władzy publicznej, należy wskazać, iż sformułowanie „każdy” oznacza każdego człowieka lub podmiot prawa prywatnego, baza orzeczeń.nsa.gov.pl.

4 Zob. druk sejmowy nr 2094/II kad.

5 LEX nr 1246684. 
nych $w$ tej ustawie zasadach. Przy czym sformułowanie „każdy” należy rozumieć, jako każdy człowiek (osoba fizyczna) lub podmiot prawa prywatnego.

Poglądy powyższe podzielił Wojewódzki Sąd Administracyjny w Gdańsku w wyroku z 5 listopada 2014 r., sygn. akt II SA/Gd 589/14, ${ }^{6}$ przypominając jednocześnie, że przy interpretacji art. 2 u.d.i.p. nie chodzi o zawężenie dostępu do informacji publicznej wyłącznie do osób fizycznych posiadających obywatelstwo polskie, ale że omawiane uprawnienie przysługuje także obywatelom innych państw, bezpaństwowcom oraz osobom prawnym i jednostkom organizacyjnym nieposiadającym osobowości prawnej, takim np. jak stowarzyszenia ${ }^{7}$. WSA uznał, że zasadne jest przyznanie takich uprawnień wyłącznie podmiotom prawa prywatnego. Termin „każdy”, użyty w art. 2 ust. 1 ustawy, nie może odnosić się do organów administracji publicznej, gdyż celem ustawy jest zapewnienie dostępu do informacji o stanie spraw publicznych, a nie umożliwienie organom administracji pozyskiwania informacji od innych podmiotów publicznych lub podmiotów realizujacych zadania publiczne czy też dysponujacych majątkiem publicznym. Zgodzić się bowiem należy, że „przepisy ustawy o dostępie do informacji publicznej nie sa narzędziem prawnym, które ma służyć organom administracji publicznej do wzajemnego przekazywania informacji. Tutaj maja zastosowanie przepisy konstytucyjne oraz administracyjne przepisy ustrojowe. Natomiast ustawa o dostępie do informacji publicznej służy społecznej kontroli władzy publicznej przez społeczeństwo.”(vide P. Szustakiewicz, „Ius Novum” z 2010 r., nr 2, s. 197).

Mając na względzie powyższe argumenty w powołanym wyroku, WSA w Gdańsku uznał, że wójt gminy, będący organem administracji publicznej, nie był uprawniony do wystąpienia o udzielenie informacji publicznej w trybie ustawy o dostępie do informacji publicznej. Sąd ten podkreślił, że: [w]ykonywanie ustawowych zadań organów administracji nie może bowiem odbywać się przy wykorzystaniu ustawy, której celem jest zagwarantowanie obywatelom prawa do informacji publicznej.

2. Podobne stanowisko jest prezentowane w doktrynie. Dla przykładu B. Baran, K. Południak-Gierz w artykule Aspekt podmiotowy udostepniania informacji publicznej na przykładzie regulacji polskich i szwedzkich ${ }^{8}$ uznają, że pojęcie „każdy” z art. 2 ust. 1 u.d.i.p. należy rozumieć jako każdy człowiek lub podmiot prawa prywatnego. Ich zdaniem termin „każdy” nie może być inaczej rozumiany, zważywszy na cel i sens ustawy o dostępie do informacji publicznej, przyjętej dla urzeczywistnienia idei transparentności władzy publicznej.

W ten sam sposób pojęcie „każdy” interpretuje J. Taczkowska-Olszewska, stwierdzając, że celem ustawy o dostępie do informacji publicznej jest informo-

\footnotetext{
LEX nr 1603595.

Zob. wyrok Naczelnego Sądu Administracyjnego z 3 stycznia 2013 r., sygn. akt I OSK 2244/12.

8 „Przegląd Prawa Publicznego” 2017, nr 10, s. 34.
} 
wanie obywateli o stanie „spraw publicznych”, a nie zdobywanie przez organy administracji publicznej informacji od innych podmiotów ${ }^{9}$.

P. Szustakiewicz w komentarzu do art. 2 u.d.i.p. ${ }^{10}$ stwierdza, że organy administracji publicznej nie mogą skutecznie domagać się dostępu do informacji publicznej na podstawie ustawy o dostępie do informacji publicznej, ponieważ pojęcia „każdy” nie można utożsamiać z organem administracji publicznej. Autor ten, przywołując orzecznictwo i poglądy wyrażane w literaturze, uznaje, że ustawa o dostępie do informacji publicznej ustala reguły, według których to podmioty spoza administracji mają kontrolować administrację, a nie administracja ma kontrolować samą siebie. Jednocześnie w komentarzu tym znajdujemy odniesienie do poglądu wyrażonego przez M. Jaśkowską, która w glosie do postanowienia Wojewódzkiego Sądu Administracyjnego w Warszawie z 18 lutego 2010 r., sygn. akt II SAB/Wa 197/09, ${ }^{11}$ uznała, że niekiedy organ administracji występuje jako osoba prawna, a więc może w takiej sytuacji składać wniosek o udostępnienie informacji publicznej ${ }^{12}$. P. Szustakiewicz stwierdza, że takie stanowisko jest możliwe, gdy chodzi o organy społeczne (takie, jak organizacja społeczna lub organ samorządu zawodowego), które wykonując zadania zlecone, działają jako organ administracji, ale dotyczy to sytuacji, gdy taki podmiot wykonuje zadania niezwiązane bezpośrednio z wykonywaniem działań jako organ administracji publicznej. W związku z tym P. Szustakiewicz uznaje, że pogląd wyrażony przez

9 J. Taczkowska-Olszewska, Dostęp do informacji publicznej w polskim systemie prawnym, Warszawa 2014, s. 256.

10 M. Bidziński, M. Chmaj, P. Szustakiewicz, Ustawa o dostępie do informacji publicznej. Komentarz, Warszawa 2015, s. 25 i n.

11 OSP 2011, nr 9, poz. 94, s. 655.

12 Zdaniem M. Jaśkowskiej: podmiotami uprawnionymi do wnioskowania o informacje publiczne moga być także takie, które w innych sytuacjach moga być podmiotami zobowiąanymi. Generalnie rzecz biorac, nic nie stoi zatem na przeszkodzie korzystaniu przez podmioty administracji publicznej, nawet przybierające status organu, z uprawnienia, z jakiego moga one korzystać, będac jednocześnie podmiotem prawa prywatnego - podaję za P.M. Sitniewskim, Dostęp do informacji publicznej, 2014, LEX, pytanie 5. Autor ten stwierdza: M. Jaśkowska przywołuje jako przykład takiego rozumienia zakresu podmiotowego prawa do informacji publicznej postanowienie NSA z 2009 r., w którym skład orzekajacy uchylit postanowienie WSA odrzucajace skarge Prezesa NBP na bezczynność Ministra Finansów w zakresie dostępu do informacji publicznej (postanowienie NSA z dnia 28 października 2009 r., I OSK 508/09, CBOSA). W postanowieniu tym NSA wyraził opinie, iż „fakt, że NBP jako osoba prawna działa na szczególnych warunkach - nie wyklucza możliwości uzyskania przez NBP informacji o działaniu organów władzy publicznej $w$ trybie przepisów ustawy o dostępie do informacji publicznej, jeżeli zakres wniosku o udostępnienie informacji publicznej nie wynika z zakresu współdziałania NBP, jako banku centralnego z organami władzy publicznej”. 
M. Jaśkowską nie jest możliwy do przyjęcia w stosunku do organów administracji rządowej lub organów samorządu terytorialnego.

P.M. Sitniewski, odnosząc się do stanowiska M. Jaśkowskiej, stwierdza: Prawo do informacji publicznej, w moim przekonaniu, przysługuje podmiotom usytuowanym na zewnatrz wobec struktur szeroko rozumianej administracji publicznej. Nie jest to prawo konstytucyjne, z którego miałyby korzystać podmioty publiczne, chcace uzyskiwać informacje o innych podmiotach publicznych. Prawo do informacji publicznej należy traktować jako prawo do bycia poinformowanym, które zostało przewidziane jako instrument szeroko rozumianej kontroli społecznej, sprawowanej wobec organów władzy publicznej i innych podmiotów, którym przysługuje tzw. imperium publiczne $w$ celu wykonywania zadań publicznych. Dlatego te $\dot{z}$, moim zdaniem, przyjęcie bardzo szerokiego zakresu podmiotowego prawa do informacji nie zawsze będzie właściwe. Kontakty pomiędzy instytucjami publicznymi sa regulowane przepisami szczególnymi, określajacymi zarówno elementy proceduralne, jak i materialne oraz podstawy ustrojowe dla tego typu kontaktów. (...) konstytucyjne prawo do informacji publicznej zostało stworzone z myśla o „rządzonych”, nie zaś o „rządzacych”. Jest to prawo, z którego moga korzystać obywatele, ich grupy, stowarzyszenia, fundacje, parafie itd., właśnie dlatego, że chca się dowiedzieć, jak sprawuja władze „rzadzacy”. Nie jest to prawo właściwe dla kontaktów pomiędzy „rzadzacymi”, ale jako instrument kontroli sprawowanej przez „rządzonych” wobec "rzadzacych"13.

Reasumując, należy stwierdzić, że w świetle powyższych stanowisk judykatury i doktryny zasadna jest teza, że ustawa o dostępie do informacji publicznej nie przewiduje uprawnienia organu administracji publicznej do występowania do innego podmiotu zobowiązanego na podstawie art. 4 ust. $1^{14}$ tego aktu ${ }^{15}$.

13 P.M. Sitniewski, Dostęp do informacji publicznej, op. cit., pytanie 5.

14 Art. 4. 1. Obowiazane do udostepniania informacji publicznej sq władze publiczne oraz inne podmioty wykonujace zadania publiczne, w szczególności:

1) organy władzy publicznej;

2) organy samorządów gospodarczych $i$ zawodowych;

3) podmioty reprezentujace zgodnie z odrębnymi przepisami Skarb Państwa;

4) podmioty reprezentujace państwowe osoby prawne albo osoby prawne samorzadu terytorialnego oraz podmioty reprezentujace inne państwowe jednostki organizacyjne albo jednostki organizacyjne samorzadu terytorialnego;

5) podmioty reprezentujące inne osoby lub jednostki organizacyjne, które wykonują zadania publiczne lub dysponuja majątkiem publicznym, oraz osoby prawne, w których Skarb Państwa, jednostki samorządu terytorialnego lub samorzadu gospodarczego albo zawodowego mają pozycję dominująca w rozumieniu przepisów o ochronie konkurencji i konsumentów.

15 Tak: I. Kamińska, J. Matarewicz, M. Rozbicka-Ostrowska, Komentarz do spraw administracyjnych, 2015, LEX. 


\section{Podsumowanie}

- W świetle poglądów wyrażanych w judykaturze oraz doktrynie celem ustawy o dostępie do informacji publicznej jest informowanie obywateli o sprawach publicznych, a nie zdobywanie przez organy administracji publicznej informacji od podmiotów należących do tej administracji.

- Organ administracji rządowej nie ma obowiązku udostępnienia informacji organowi administracji samorządu terytorialnego na podstawie ustawy o dostępie do informacji publicznej, ponieważ np. organy gminy nie mogą być zakwalifikowane jako podmioty określone w art. 2 ust. 1 tej ustawy.

- Odnosząc powyższe rozważania do stanu faktycznego, należałoby uznać, że organ gminy nie jest uprawniony do ubiegania się o udostępnienie informacji publicznej (w tym np. udostępnienie korespondencji poselskiej związanej $\mathrm{z}$ interwencją poselską) $\mathrm{w}$ trybie ustawy o dostępie do informacji publicznej.

\section{Bibliografia}

Baran B., Południak-Gierz K., Aspekt podmiotowy udostępniania informacji publicznej na przykładzie regulacji polskich i szwedzkich, „Przegląd Prawa Publicznego” 2017, nr 10.

Bidziński M., Chmaj M., Szustakiewicz P., Ustawa o dostępie do informacji publicznej. Komentarz, Warszawa 2015.

Kamińska I., Matarewicz J., Rozbicka-Ostrowska M., Komentarz do spraw administracyjnych, 2015, LEX.

Sitniewski P.M., Dostęp do informacji publicznej, 2014, LEX.

Szustakiewicz P., Glosa do postanowienia Naczelnego Sądu Administracyjnego z dnia $28 X$ 2009, Sygn. akt I OSK 508/09, „Ius Novum” 2010, nr 2.

Taczkowska-Olszewska J., Dostęp do informacji publicznej w polskim systemie prawnym, Warszawa 2014. 